Sonja Petrov ${ }^{1}$

Vesna Zubac ${ }^{2}$

Miroslav Milojević ${ }^{3}$

University Union - Nikola Tesla,

Faculty for business studies and law, Belgrade
SCIENTIFIC REVIEW ARTICLE doi:10.5937/ekonomika1502153P

Received: December 30, 2014

Accepted: April 20, 2015

\title{
SOCIAL NETWORKS AS MARKETING CHANNELS
}

\begin{abstract}
Fast technological development in social media offers many opportunities for companies in order to have better connection with their customers. Traditional tools become less effective and companies are working intensively to be present on the web. This paper will try to answer the question what are the advantages of social media as a marketing channels compared to conventional way of advertising. The authors will specially pay attention to how can companies improve and increase their presence in social media by using different strategies and which tools and services can be used in order to have better connection with the customers.
\end{abstract}

Key words: social media, social networks, visual marketing, tools and services of social networks, the Internet

JEL classification: M3, M30, M31

\section{ДРУШТВЕНЕ МРЕЖЕ КАО КАНАЛИ МАРКЕТИНГА}

\section{Апстракт}

Брз технолошки развој у друштвеним медијима нуди нове могућности за компаније да се боље повежу са својим купцима. Традиционални алати постају мане ефикасни и компаније интензивно раде на својој онлине присутности. Овај рад покушаће да да одговор на питање које су предности друштвених медија као канала маркетинга у односу на класичан начин рекламирања. При томе, посебно ће се сагледати како да компаније унапреде и повећају своју присутност у друштвеним медијима користећи различте стратегије, као и који суто алати и сервиси које могу применити у цицьу веће онлине повезаности, односно како да се на најбољи могући начин повежу са својим купщима.

Кључне речи: друштвени медији, друштвене мреже, визуелни маркетинг, алати и сервиси друштвених мрежа, Интернет

\footnotetext{
${ }^{1}$ sonjap73@gmail.com

2 zubacvesna@gmail.com

${ }^{3}$ miroslavrmilojevic@gmail.com 


\section{Introduction}

In nowadays we can find marketing everywhere. Whether we like it or not, formally or informally, organizations and people are involved in a number of activities that could be freely called marketing. It significantly influences our everyday life; good marketing is increasingly becoming a key for the success of a business. We can also say that good marketing is not accidental, but is the result of detailed planning and realization. If there have only been attempts in the beginning of the 21 st century to anticipate what will happen in the field of marketing, I think we could not imagine how far the way of presenting brands and services can go and how it is necessary that we are constantly up to date with marketing trends.

The beginning of the $21^{\text {st }}$ century brought a new concept of creating a multitasking $e$-business platforms that have allowed the current exchange of information and knowledge and the simplified usage of increasingly complex opportunities in the online environment. Since the Gutenberg's discoveries of modern printing machines for more than five hundred years ago, which made books and scientific papers widely available to the masses, not a single new invention has encouraged individuals, and transformed access to information as thoroughly as Google. The quest for current information on anything and everything ends with "googling" via computer or mobile phone (Vise \& Malseed, 2011, p. 15). We believe that today there is no person who has not heard of the term "social network", a phenomenon that has reached unimaginable proportions and opportunities in the field of marketing. In recent years, the term social media or social network is adopted, which includes various types of very influential and visited services such as social networks (Facebook, Google+, MySpace, Pinterest, Twitter, Linkedin ...), systems of content aggregation (Vesti.rs, News.google.com, Blogodak. com...), multimedia social services (Flickr.com, Ustream.com, YouTube.com ...), social bookmarking systems (StubleUpon.com, Delicious.com ...) as many other services that are based on the active participation of users.

\section{The advantages of social media marketing compared to traditional marketing}

In nowadays, more than ever, managers of companies from the region of old economy need the right tools that will support and promote their effectiveness in making major strategic moves, allocating the lack of resources and managing the risk. Why is that so? Because the large companies from the old economy - from manufacturers of goods of wide consummation to industrial consumption - began to realize that new companies take a relatively small part of their market that do business via the web. As a result, these companies became interested in danger that e-commerce brings and turned to more efficient digital strategies, based on optimization of users activity, the integration of their chain value and accelerate the flow of information (Kalakota \& Robinson, 2002, p.77).

Changing the way of making businesses in the global marketplace leads to changing the rules of exposure in social media in order to provide the best way to respond to the 
needs of the continuously variable market. Regardless of whether you are a small or large company, social networks and media today represent a powerful channel connection with customers and potential customers. We can say freely that social networks today offer the potential for incredible opportunities as no other marketing way so far. By giving such great importance to social media today, we must agree that it is therefore particularly important to create and implement a strategy that will be effective and have positive results.

In the past, customers had to work hard in order to gather information on suppliers from around the world. On the Internet, customers come easily to large amounts of information. Sources of information are: (1) the website of the supplier; (2) info mediators, third parties that add value to the gathering of information on alternatives; (3) market makers, third parties that create markets by connecting buyers and sellers, and (4) consumer community, a website where customers can exchange stories about the supplier's products and services (Abler, Adams \& Gould, 1971).

With the appearance of social networks and their ever-faster development, the well set ways of business models are also changing. Social networks are the ideal platform for building and running a positive online PR strategy and the "world of mouth" marketing. There are millions of connected surfers, potential clients, partners, customers, consumers and even competitors gathered at various locations. These groups focused in this way make almost an ideal aim for an army of marketers, advertisers and an ideal field for performing sophisticated communication activities (Mirković, 2009, p. 12).

The purpose of any marketing is a line of business activities and actions taken in order to direct the goods and services from producers that is a trader to the consumer. If we consider some of the characteristics of traditional marketing such as communication in one direction, a closed system, the mass marketing, controlled communication, passive participation, formal language, platform that is paid, as opposed to marketing through social media and networks which bring two-way communication (two -way conversation), an open system, transparency, one on one marketing, it is not a story about me, but it is about you, the authenticity of the content, a platform that is not paid (Facebook, Twitter, Google + ....), the active participation of the users of our services and many other advantages, tells enough about the immeasurable advantage of this second model of exposure compared to the classical way. Meaning that the current form of traditional marketing, which included product advertising and services with insufficient information and market exploration, is slowly forgotten and it is linked to the business over the Internet.

Basic features of social media (Social Media) are simple participation of users and content that users generate (User Generated Content). The importance of content is reflected in the fact that social media are becoming more influential with increasing content of users (for example.Wikipedija.org). Social networks present a very important part of social media with increasing impact on business.

Companies use social media (Social Media Optimization - SMO) for the achievement of the stated goals of the company it actually presents the design and implementation of different methods of communication via social media, which result in generating publicity. In implementing that task into action, we can ask ourselves:

- What the optimal number of using social media is or whether "an optimizing strategy of social media" is done: 
- Whether it is necessary to study and use all the familiar social media;

- Is it enough to be included in only one social medium (for example Facebook or Twitter)?

At what level will social media as a marketing channel be represented in a company depending on the consciousness of their strong influence on the possibility of improving the business, because whether we like to admit it or not, if the company is not present in social networks is the same as that it does not exist. However, although the understanding of different companies about their significance, according to the survey of Hubspot.com there are the following results:

- $\quad 92 \%$ agrees that social media (social media) is relevant to their business, which has increased compared to 2013 when the percentage was $86 \%$;

- $80 \%$ agrees that investing in social media has generally increased the turnover;

- $72 \%$ confirms that social networks used to achieve the loyalty of current and future users;

- More than half of the users of social media that were present within them for the last three years, confirms that this helped them increase the turnover;

- $74 \%$ of users who have spent more than 40 hours a week using social media received several job offers;

- More than half of the users who have invested in social media at least a year also tell about increasing the actual contacts and new business results;

- The total number of those who have used social media for at least one year, $69 \%$ confirmed that it has built a larger base of loyal consumers.

Even though this confirms the fact of the great potential of marketing through social media, it is necessary to know how to reach and achieve these results. As some of the ways that companies may improve their business could be (DeMers, 2014):

- Increase the brand recognition - the circumstances require the use of every opportunity to increase the visibility of the brand or company, and social media are just a powerful marketing channel promotion of what you do;

- Improve the brand loyalty and the company - according to the survey undertaken by Texas Tech University (Bell, 2013) brands that use the way of their promotion channels through social media enjoy greater loyalty to their clients. A further conclusion is that companies should take advantage of social media tools that allow them a greater connection with a wider audience;

- More opportunities to attract new clients - each video, blog post, video content or comment that you share present an opportunity for someone's comment, response, conversation, all of which can contribute to visiting the website of the company itself, which means greater opportunities for new business. Even though it won't have the same number of positive responses to posts every time, each post company make in social media is an opportunity for gaining new customers;

- Higher level of great results - can be achieved in several ways, but the most important is the human factor, and the thing is that brands are becoming much closer to the people with interaction through social media. This is where brands can act like humans because an individual likes to deal with another individual, not with the company; 
- Increased visit to the company's website - without the use of social media attendance can generally be limited to people who use the company's brand. Putting the profile of the brand on various social media gives a chance for new visitors;

- Greater authority of the brand - as in everyday life, when people want to hear compliments about a product or a service, the first thing they will do is to go to one of the social networks or media. The moment they type the brand name, a new potential consumers will want to know what is new that we are offering. What proved to be correct, is that the more people are talking about company on social media, the greater value brand will have for new users, and not to mention, if someone have the opportunity to connect with the most influential people on Twitter $-\mathrm{u}$, the visibility of the brand will be immeasurable;

- Lower costs of marketing - advertising through social networks may be more favorable than the classic form of advertising, for example through Facebook and Twitter, depending on the goals we want to achieve;

- A better position when searching - Google and other search engines take into account the presence in social media as an important factor when ranking search because it is seen and understood that a strong and significant brands use social media. Being active on social media provides a signal that a brand is legitimate, credible and something you can trust. We can conclude that presence is simply necessary;

- More colorful experience with clients - social media is something like a phone call or an email. Every interaction we have through social media is an opportunity to present our brand in a way that will lead to creating the connection between us and our customers. It is very important that if a client complains on or praises us through a social network, in either case, it is necessary to respond, either in the form of an apology and promise that we will correct the error, whether we will thank for positive comments. What is important is the personal experience of the client who then knows that we care about his opinion;

- Better insight about what people think of brand - listening, or reading carefully the comments on social media, we can get a picture of what people think of the brand they are using and the company.

Here are listed some of the benefits of active usage of social media in the long term, but surely we must be keep in mind that our competition present is also present in those same social media and it carefully monitors our activities, which means that time is running out and if we have not used them so far, it's time to start applying them.

\section{Creating marketing strategies on social networks}

Past 2014 was a year of enormous growth in the field of social networks, as illustrated by the fact that over the social network Twitter during the day more than 500 million twits were posted, the social network Instagram posted over 35 million images 
and the members of the social network Facebook posted 350 million photos each month. Social media present more than mere entertainment and communication with friends. Today, they can be a very powerful marketing tool for your business, if we have made a strategy. Changing the way of doing business of commercial operators in the market, carries with it a change in the rules of exposure in social media, in order to achieve a better interaction in responding to the needs of the constantly changing market. We can freely say that social media and networks, today offer great potential for amazing opportunities and if we are not present in it, we are losing a big chance in winning new users of our services. So much power and importance of social media show some of the following statistics based on the research that is conducted by Search Engine Journal (Jones, 2013) - $72 \%$ of the total number of Internet users are active in the social networks; $89 \%$ is 18 to 29 years old; $72 \%$ are between $30-49$ years of age; $60 \%$ of active users between the ages of 50 to 60 ; and $43 \%$ of users are over 65 years old. When we talk about the time spent on Facebook the United States take the first place, the Australians are the second, while the British are the third; $71 \%$ of users of social networks are connected via mobile phone. Social network Facebook is still the largest social network, but some predictions say that Google+ could replace it in 2016. Facebook has over 1.5 billion users, about one million of websites is offering to login through Facebook ("Login with Facebook"), about $23 \%$ of its users logs in at least five times a day, $47 \%$ of Americans say that for them Facebook is the number one by the influence on the purchase, while $70 \%$ of trade uses Facebook to acquire new clients. As for the social network Google+, it now has over one billion users; it reaches about 359 million of active users per month, while the number of users is increased by $33 \%$ per year. If one takes into account the fact that Google + as a social network exists only for about three years, it is certainly a success. Social network Twitter today has more than 550 million registered users, and during 2012-2013 he was the fastest growing social network, it has 215 million of active users, $34 \%$ of trade uses it as the number one of the social networks. During the last period, Twitter has made a few visual enhancements which are one more reason to use it in your business. There are some other social networks that certainly should not be passed by are the Pinterest with over 20 million active users per month, Instagram 150 million of active users per month, then YouTube, Tumbir, Linkedin, Vine, Slideshare and many others. Creating marketing strategies on social networks involves many identical elements as well as classic marketing strategies. The survey of targeted market and consumer habits is obligatory. It also means identifying the strengths and weaknesses of the brand or service you offer. The elements that could be part of your strategy on social networks are:

- Defining what is target market, which means to be familiar with the ways of using social media and networks in different demographic areas, to understand how, when and why the target market uses social media and networks;

- Make time to think what will our content do on social networks - this means that each set post, blog or message must serve the realization of the goal, but should also not lose sight of the result, which is still used for new directions in a social media campaign;

- Appoint a person to the position of a manager of social media (social media manager) - it is necessary to have a person or several people, depending on the size of the company, which will be responsible not only for monitoring and respect of the content, but also to respond to comments and to provide 
feedback. Consumer surveys show that the most significant inhibitors lack of affordable online shopping experience, social interaction and personal consultation with a representative of the company (Barlow, Siddiqui \& Mannion, 2006, p. 157). Companies have started to react; many of them now offer live online communication to immediately advise potential customers about the products and the proposed purchase of additional items. When there is an active sales representative, the average amount per order is usually higher. Marketing experts on the market of business spending (B2B) should also put a human face on their presence in e-commerce, and some are taking advantage of the Internet 2.0 technologies such as virtual environments, blogs, online video and chat (Kotler, Keller \& Martinović, 2014, p. 439);

- Creating a page for brand or service - first we need to determine is which social media sites we want to use, or where we want to be present. For small business the recommendation is to use Facebook, Twitter and Google+, and in some cases, depending on the activities that we do, it can be Pinterest, Linkedin or Houzz. What is important is that all the social media that use the created visual appearance is identical to the website of our company. After we have created the page, make sure that it includes links to the website of our company as well as to invite all members to join us on social networks where we are;

- Develop an action plan on social networks - it is not enough just to create a presence on social networks, but it is necessary to constantly inform the public about developments in the company and for this reason it is necessary to make a plan that will include a number of weekly posts, the time when the content will be put, what the content will be;

- Generating an interesting content - includes presence on social media it does not end with determining the person responsible for social networking, creating identity and making a plan. The strategy further includes generating the interesting content, and it can help us to set ourselves as we are in the role of our customers and clients and thus to discover what it might be interesting to them and what content would our followers on to the social networks wanted to share further. Creating such content is the fastest way to gain new followers (weekly tips, healthy humor content, interactivity - asking questions that people will want to respond, visual and video content, sales or special events);

- Monitor constantly the responses and results - driven by the imperative is to follow comments; either positive or negative, it is necessary to respond in short notice. If someone praises our product or service, be sure to thank him. If we have a complaint, we will try to find a reason and it is always important to explore why someone has a negative comment and send feedback. This information helps us to better understand the reactions to our products or services and to work on the improvement and to make them even better;

- Use the results to better understand the onsumer behavior and their response to our products and services - what better way to get information about our product or service, if we do not just ask those who use them, or our customers, and we should not be afraid of the answer. By doing so, we give ourselves 
the opportunity to get to know our strengths and advantages but weaknesses and shortcomings as well. The sooner we respond to comments we create a greater connection with the customers. As a good example of customer we can name a multinational company Walmart (http://www.walmart.com/) which seeks to find a solution to all the problems that the users of its services face;

- Cross-marketing strategy - experiences of the most successful companies in the world have shown that the creation of cross-marketing strategy yields positive results, and that includes our simultaneous presence on social networks (for example Google + and Pinterest are connected with Tumbir and Linkedin, Twitter and Facebook with Instagram);

- Making variations - this means that company does not get stuck with the same "old pictures" since appeared on the social networks so to this day. As best strategy proved to be a strategy which contains modifications, changes, mixing regardless of whether it is related to the link, image, text, or post;

- Abide by the rules 70-30 - this would mean that the greater part, or $70 \%$ of the content that we post should be the content that will encourage active participation and interaction of our current and potential customers, and the rest should make a promotion. As for the content, it should be primarily useful and interesting to our followers on the Internet, which allows better connection and the fact that the company respects their opinion;

- Track trends, analyze, examine, make corrections - today social networks are filled, large database of statistical data and analysis that can be helpful in creating better marketing strategies in social networks, and also there is a huge number of applications and services that will serve to obtain the relevant statistical data on how to present ourselves in the best possible way, to improve and upgrade strategies. Knowing that social media and network are constantly changing, it means that we constantly have to analyze, to investigate steps we have made, to make adjustments and be flexible in accordance with the trends.

\section{Tools and services for promoting the content on social networks}

Regardless of whether create the absolute best content, the question that should ask is: how to reach the people we want to attract to its content? Posting articles or content for example on blog is just one of the ways of promoting the brand, and goal is to attract the target audience about what company does (Kuenn, 2014). There are different tools and platforms that can help in promoting the brand and can facilitate reaching the largest possible number of visitors. Some of the tools and services are the following:

1. HootSuite - this platform was originally designed to be optimized and managed by the users of Twitter, but it was also used to make posts from personal profiles on Facebook and Linkedin. Unfortunately, this service does not connect profiles from the Google+ social network, but allows us to manage our Google+ page on this service. Today it is the social media management for any company, providing us to manage our brand through s 
social network, schedule for setting posts, greater visibility and measurement of results. It is a perfect tool for small and enterprises, agencies, but also for corporations and state-owned companies that have the need for management, engagement and measurement via the intuitive platform where we are given the opportunity to be associated with more than 35 popular social networks. The ability to make a timetable posts on HootSuite in a very powerful tool, allowing companies to make plans and to be in touch with the visitors in just a few simple steps.

2. Google+ - after the beginning at a low level the social network Google+ has reached a figure of more than 300 million active users compared with Twitter which has 270 million users. Although it is not as popular social networks like Twitter and Facebook, Google+ is becoming a place that we cannot skip as it concerns the promotion of our brand. What is good on Google + is that allows us to put the link of the brand or the company directly on our profile page thus allowing content to be more visible to people who are involved in our region or by simply using the link. So called "Hashtag" plays a very important role in the promotion of content, it is marked with the sign \# and gives a greater possibility that someone will notice our brand with the help of a key word and it is related to the post on this social network.

3. Followerwonk - Followerwonk is a tool for users of Twitter, and it gives the possibility to monitor, analyze and optimize our way of presenting at Twitter. This tool will help us find out who our followers are, where they are from, when they post a twit, then we can connect with influential people within the field of our interest, to work graphical comparisons with other users, the presentation of content is simple, etc. As the most useful function of this service we can mention "Search Twitter Bios" which offers the possibility of finding the most popular Twitter profiles within our field of interest. For example If someone is a person who is engaged in internet marketing, he can type the word "SEO" or "Link building" in the search field, and Followerwonk will give him suggestions for all Twitter profiles that contain characteristic words "SEO" or "Link building" or they somehow connected to a given word in their Twitter profiles. Some of the well known users of this tool are Xerox, MerrillLyndh, Pingdom, Rhapsody, IMAX and many others.

4. Taboola - believe it or not in nowadays Taboola as a platform is the world leader in the discovery of significant content, it works with over 150 billion of the recommended content, reaching 400 million visitors each month, including the USA Today, The Weather Channel, The Atlantic, Fox Sports and so on. Taboola studies the behavior of visitors when they interact with the content that predicts which web sites are the most interesting to visitors. Taboola is significantly focused on video content for the simple reason that it is the best way to display the message we want to convey which is confirmed by the CMO.com (Abramovich, 2013) that says that users are 27 times more likely to click on the link for online video content than it will do for the standard banners.

5. BuzzStream - BuzzStream represents a popular service that helps to create so called buzz for our content, to post links and increase the visit to our site so 
that we will be "found" or tagged through various marketing channels. This tool is designed to help the best web marketers to promote their products, services and content. BuzzSumo is a supplement to BuzzStream and helps people who are engaged in marketing to find content with a high sharing and influential companies of specific professions.

6. Contently - this service and tool helps brands to create entertaining stories to engage visitors to actively participate and to present the results in scales. It will not only help us in creating the content, but it will also assist us in identifying the best promotional strategy for any type of business or brand. Some of the major companies that use this service are Coca-Cola, Google, Walmart, GM and others.

7. Outbrain - Outbrain is an important tool that makes the categorization of content and displays it to visitors based on their online behavior. It helps in increasing the attendance of individual blogs, posts or articles, visual content, content that is distributed via mobile phones and much more. All the big companies that do not depend on the type of activities they are involved in consider this service to be indispensable. This service offers a much more personalized experience for our visitors, it displays our content in a context that visitors are willing to participate actively it directs us to improve results, to redefine its media strategy and etc. Each advertisement via Outbrain that is all contents are checked for quality and the categorization depending on the topic, which in other words means that you cannot advertise any content. Some of the known users of this service are CNN, Allstate, NBCNEWS.com, MarketWatch and many others.

8. StumbleUpon-This service includes displaying content through understanding personal interests of users that begins with a brief overview of the categories when creating a profile, but the number is growing as the content is used. Users by clicking on "stumble" button which is located on the toolbar have the option to mark the content if they like it or not, the content of people who rank it positively is more likely to be offered to them when there is a new search. Considering this possibility, from these data, we can see a number of different trends, like: "Recently Hot" tags, these tags are actual people whose content we tagged, then the "Most Popular All Time" tags, they are much less likely to change, but we can change it by exploring deeper content, then "Stumbles by topic" that shows activity depending on the chosen theme and "Top Rated websites" refer to pages that are most popular by users of this service.

9. Facebook (Ads) - this certainly is the biggest social network and certainly a place of great opportunities to promote our content. Within these social networks we have three main locations where we can choose to make our content public, such as: Newsfeed, this is the most popular place on Facebook for placing advertisements or contents because of this ads seamlessly appear along with the other content that can be seen from friends and people who follow; then there is Mobile, at the beginning of this year the number of users of these options amounted to a staggering 1.01 billion active mobile users on the social network per month, which means that our ad or content 
should tend to be optimized for mobile phones because this is definitely a great opportunity to make our content visible and "Right-Hand Column", this option is visible below the "Trending" top sections. The benefit of this option is that here placed advertisements moves downwards together with further research site users and it is always visible. This would mean that with advertising on Facebook we have the ability to reach the largest audience in the world like never before.

10. Pinterest - this social network is based on the visual content in the form of an album where users according to their interest open so-called "Boards" or tables in which they store images and visual content that is becoming extremely shared with success. Putting the option "On Hover Pin" and "Pin" addition to all the visual content on our website, we encourage people to pin or insert our content to their boards. This is a great opportunity and a possibility to make our content via Pinterest visible for many people as possible and so to encourage our site visitors to follow us on Pinterest, as well as giving us the opportunity to increase our chances of making a new business and cooperation.

\section{Tools and services of social media that can be useful for small business}

Considering the need for constant presence on social networks and media, which requires a lot of time, here we list some of the tools and services that can significantly facilitate the work, and appear to be very useful and functional. No matter which tool we choose to use, be sure that they will bring us efficiency and the ability to interact within online communities.

As for management, or managing the content of the company or posts on social media, the first useful tool would be Sprout Social, strong social media software, designed for business through which we can check, supervise and monitor our presence on social networks. Also, this tool has an automatic scheduling of content updates to multiple social platforms. Another useful tool or service that has its own daily use is Buffer that allows us to do the time planning of our posts on social media so that we make the order of their appearance on social networks. If you find the content that we would like to share, we can add it to our Buffer account from our browser or mobile device and it will automatically be posted in accordance with pre-made schedule for publication. When we talk about the data analysis, a useful tool could be already mentioned above the Followerwonk. It solves our dilemmas about when is the best time to, for example, publish the content on Twitter and it will automatically pull the schedule in our account that we have on Buffer. If we want to increase our presence on Facebook, Google+, Instagram, Twitter, LinkedIn, Vine or on any another social network, Simply Measured is a tool that will allow us to do that. This service offers free reports where the analysis of our profiles is done on various social networks, helping us to post content at the right time and at the right place. Some of the big companies that use this service are Samsung, Pepsi, Hyundai, Adidas, Microsoft, Whole Foods, AOL and many others. As for the search, SEMRush could be a useful service. If we want to understand better whether 
we are using adequate key words or how potential customers find our competition on the web, there is SEMRush to help us (Philips, PayPal, Forbes, Hyatt, and National Positions). BuzzSumo is another service that is essential for the search. BuzzSumo will give us the way to peek of what is going on in the minds of our customers to browse the contents and identify important competition. BuzzSumo is a great place where we can find out which topics are related to our business that attract the most attention, to see which content is a good one and which companies have the greatest impact on the business we are involved (Spotify, WMG, HubSpot, Wyatt, DigitasiLBi). Regardless of the social network, finding the content that will be of interest to our visitors sometimes it can be a great challenge. And if we think about it happens very often that we have a problem to find the content that we would like to share. We have also PostPlaner to help. Directly integrated with Facebook, PostPlaner identifies popular content on Facebook, selects and organizes them into our PostPlaner profile where we can easily continue to manage any of our Facebook pages. Swayy tool which connects our site on Twitter, LinkedIn and Facebook, allows us to see the most popular content of these pages and we can directly share or post on our social media profiles. As far as the visual content, tools that can be helpful are PicMonkey and Canva. As we can notice, social networks are becoming more visual, but the question that arises is how do we come up with a good visual content without using Photoshop? Canva could solve this problem which is ideal for any business and will save us a lot of unnecessary time spent in trying to create visual design you want. Canva is a quick, easy and mostly free way in creating visual content; it provides many opportunities for different purposes of creating such content according to the type of social network where we want to publish the text, whether it is about a general social media, some presentations, graphic blog and etc. PicMonkey is very similar to Canva; it will ensure that our images and visual content are professional in the way that will make our old uninteresting graphic or picture turn into a real piece of art. It is also easy to use; it has a huge database of templates, images and graphically offered solutions. Another service of creating visual content is Photoshop Express. Adobe Systems Incorporated or just Adobe, the US software company has created a free version of Photoshop called Photoshop Express. It has many advanced features that graphics professionals use every day. But we still have fewer opportunities than of course the complete version of Photoshop, but there is still enough to create an interesting visual content. The difference between this service Canva and PicMonke is that Photoshop Express does not offer ready-made templates, but we have to find them, insert and then create. Pixlr Editor is very similar to Photoshop Express, but with even less abilities and is not of agreeable interface. GIMP (GNU Image Manipulation Program) is one of the oldest applications for processing and creation of visual content and it is also very similar to Photoshop and has a wide range of options. As far as applications and services to create visual content that is not free, but not as inaccessible as a professional Photoshop, we can mention one of the best and that is Pixelmator. If a company wants to get a seriously creative and visual content and does not want to spend more than $\$ 30$, then the application Pixelmator is for her. Another such application is Sketch, which has a very good user interface and a powerful set of features for creating complex visual contents. 


\section{How to improve the performance on social networks by using visual content}

Why should we use visual content (Visual Social Media) in social media? Of course it is because it grabs attention a lot faster than a plain text. If we take into account the fact that ninety percent of the information received is visual and that visual content process 60,000 times faster than text which visual marketing and visual content makes much more powerful tool than any other possibilities to be applicable in business. The visual content will not only contribute to our online visibility, but it also becomes unique identity because in the sea of numerous companies in social media, visual content creates our uniqueness and makes us easily recognizable. In April 2012, Instagram, a visual platform, has increased the number of its customers for ten million within ten days, but today that number is 100 million. Currently the second largest social network among the visual content is Pinterest. Considering the fact that every sixty seconds people share about 136,000 images on Facebook per day, we can understand how significant is to create visual content on social media. Pictures are powerful means of communication, as the research by MDG Advertising presents and says that content which includes visual contents are $94 \%$ more evident compared to the content that is not visual. What you want to present simply must include a good visual perception that it could be noticed by visitors. Therefore, the successfulness of the content's visual presentation means to draw attention of potential and current users of our activities and their greater loyalty. There are some ways of displaying visual content and they can be (Radice, 2014):

1. A short quote that relates to our brand (Branded Quotes) - regardless of whether we use the quotes or not on Twitter, Facebook or for example Pinterestu, opposite to the posts based only on the text, a quote with a certain visual content may constitute a recognition of our brand;

2. Infographics (Infographics: Data, Charts and Graphs): a chart, data and graphics - no matter what kind of activities they do, infographics as a means of visual representation promotes our authority and credibility and therefore presents information that encourages interaction between companies and consumers and builds thus their loyalty towards us;

3. The initiator of the conversation (Conversation Starters) - invitation to a conversation, exchange of opinions and questions are a good way to combine text with visual display. To support that there is the fact that if we just try to remember when reading information, comments, etc. on the Facebook page of our company, we will see that we usually respond to texts which are combined with the image, or when they are proactive and cause a reaction in us to respond. What we can do is to talk about current issues, share stories that our company, services or products make unique, humane, socially responsible, to give answers to frequently asked questions, ask questions that are easy to answer, etc.

4. Making a creative video presentation (Creative Videos) - although the video presentation is nothing new in marketing, for many companies it is still an undiscovered area of operation. In this sense, video presentations on social networks of companies should offer a simple and in interesting way weather information, address or party. Some of the facts we need to know when 
talking about video presentations are that about $1 / 3$ of active users watch online video content, 100 million people are watching online video every day, video presentation increases the awareness of consumers about our industry for $74 \%$, and $75 \%$ of those who have seen our video presentation and will see the company's website as well.

This means that nowadays a modern consumer depends on visual effects and the text itself is no longer sufficient to attract and keep his attention to a particular product or service. The big question might be: what content to create? The answer may be very simple, and it is to create anything that is worth the time visitors spent, but we should pay attention that the visual content, except for its attractiveness has to be in accordance with the objectives or purposes of the company and what it wants to achieve.

\section{Conclusion}

To be present on social networks and the media is no longer a caprice or a modern way to be In, but an absolute necessity and an important tool in the modern way of doing business and communication. As we have seen changing the way of doing business requires new ways of presenting companies in social media, all in order to adapt to the new rules of business. Social networks take the absolute lead as the most active marketing tool of a company towards its clients. They represent a powerful channel of connection with customers and potential customers, so that we will choose between classical marketing that makes communication in one direction and marketing through social media and networks that represents two-way communication, we will definitely choose the second because it brings many advantages - greater brand recognition, greater loyalty and authority to the brand and to the company, making new clients and business partners, increases visiting the company's website, lower marketing costs, better communication with customers, a closer insight on what consumers think about a brand, and many other advantages.

Achieving these goals, as we have seen it is possible with making adequate marketing strategies that will with the help of the appropriate tools and services within social media and networks are going to bring extraordinary results. Which tools and services companies will choose depends on the purpose and priorities that it wants to achieve. Meaning that social media give the opportunity to hear and to listen the consumers and give them exactly what they want. If are used correctly, the social media can help in achieving the set goals. And in the end, we should have in mind a few "universal" rules, that it is important that brands turn to its users, communication is expected, rather than the mere dissemination of information; a huge number of possibilities require content that can be adapted and shared in various places on the Internet; and we must not forget that social networks are the internet tool, but we must be the ones who will build a community that will work towards its objective. 


\section{References}

Abler, R., Adams, J., S., \& Gould, P. (1971). Spatial Organizations: The Geographer's View of the World, Upper Saddle River, NJ: Prentice Hall

Abramovich, G. (2013). 15 Mind-Blowing Stats about Online Video Advertising, Digital Marketing Business News, retrieved December 20, 2014 from http:// www.cmo.com/articles/2013/8/27/video_15_mind_blowing.html

Barlow, A., Siddiqui, N.,Q. \& Mannion, M. (2006). Development in Information and Communication Technologies for Retail Marketing Channels, International Journal of Retail and Distribution Management 32, pp. 157-163.

Bell, T. (2013). Establishing Brand Loyalty through Social Media, Texas Tech University - College of Media \& Communication, retrieved December 22, 2014 from http:// www.depts.ttu.edu/comc/outpost/blog/brand-loyalty.php\#sthash.GymG5BDh. QvmwLHas.dpbs, December 22, 2014

Courtland, L.B., \& Thill, J.V. (2012). Suvremena poslovna komunikacija, Mate, Zagreb

DeMers, J. (2014). The Top 10 Benefits of Social Media Marketing, retrieved November 24, 2014 from http://forbes.com/sites/jaysondemers/2014/08/11/thetop-10-benefits-of-social-media-marketing/

Jones, K. (2013). The Growth of Social Media v2.0, Search Engine Journal, retrieved November 18, 2014 from http://www.searchenginejournal.com/growth-socialmedia-2-0-infographic/77055/

Kalakota, R. \& Robinson, M., (2002). e-Poslovanje 2.0, Mate, Zagreb

Kotler, P. \& Keller, K. L. (2006). Marketing menadžment, Data Status, Beograd

Kotler, P. \& Keller, K. L. \& Martinović, M. (2014). Upravljanje marketingom, Mate, Beograd

Kotler, P., Vong, V., Sonders, Dž. \& Armstrong, G. (2007). Principi marketinga, Mate, Beograd

Kuenn, B. (2014). 10 Top Content Promotion Tools and Services. Retrieved December 11, 2014 from http://www.verticalmeasures.com/content-marketing-2/10-topcontent-promotion-tools-and-services/

Levison, J.C. \& Rubin, C. (1996). Guerrilla Marketing Online Weapons, Hoghtom Mifflin Company, NY

Milosavljević, M., \& Mišković, V. (2011). Elektronska trgovina, Univerzitet Singidunum, Beograd

Mirković, A. (2009). Društvene mreže - društveni fenomen, Profit, 16-17, pp. 12-13

Radice, R (2014). How to Use Visual Content to Improve Social Media Results. Retrieved November 20, 2014 from http://maximizesocialbusiness.com/usevisual-content-improve-social-media-results-16250/

Šapić, D. (2005). Marketing na internetu, Daniel Print, Novi Sad

Varagić, D. (2002), Vodič kroz raj i pakao internet marketinga, Prometej, Novi Sad

Vise, D.,A. \& Malseed, M. (2011). Priča o Google-u, V.B.Z., Belgrade 